\title{
Accountability in a privatized welfare state
}

The case of the German hospital market

Suggested citation referring to the original publication:

Administration \& Society, 45(3), 2013, pp. 326-356

DOI http://dx.doi.org/10.1177/0095399712451890

ISSN (print) 0095-3997

ISSN (online) 1552-3039

Postprint archived at the Institutional Repository of the Potsdam University in:

Postprints der Universität Potsdam

Wirtschafts- und Sozialwissenschaftliche Reihe ; 82

ISSN 1867-5808

http://nbn-resolving.de/urn:nbn:de:kobv:517-opus4-403251 



\title{
Accountability in a Privatized Welfare \\ State: The Case of the \\ German Hospital Market
}

Administration \& Society

45(3) 326-356

(C) 2012 SAGE Publications DOI: $10.1177 / 0095399712451890$ aas.sagepub.com

(S)SAGE

\section{Tanja Klenk' and Jonas Pieper²}

\begin{abstract}
One of the most striking features of recent public sector reform in Europe is privatization. This development raises questions of accountability: By whom and for what are managers of private for-profit organizations delivering public goods held accountable? Analyzing accountability mechanisms through the lens of an institutional organizational approach and on the empirical basis of hospital privatization in Germany, the article contributes to the empirical and theoretical understanding of public accountability of private actors. The analysis suggests that accountability is not declining but rather multiplying. The shifts in the locus and content of accountability cause organizational stress for private hospitals.
\end{abstract}

\section{Keywords}

accountability, hospitals, privatization, welfare markets

\section{Introduction: Private Actors and Public Responsibility}

One of the most striking features of recent welfare state reform is privatization and the creation of welfare markets. Public provision is on the decline,

\footnotetext{
'University of Potsdam, Germany

${ }^{2}$ University of Bremen, Germany

Corresponding Author:

Jonas Pieper, Centre for Social Policy Research, University of Bremen, Mary-Somerville-Straße 5, 28359 Bremen, Germany.

Email: jopieper@uni-bremen.de
} 


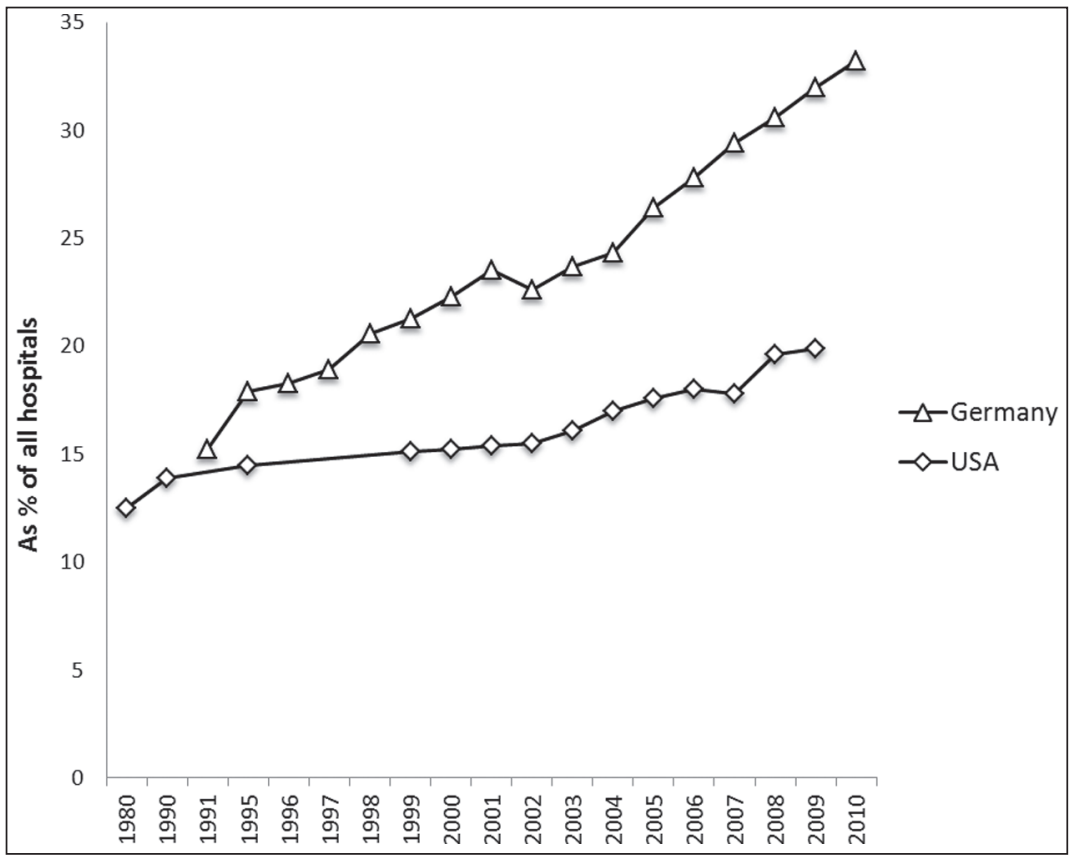

Figure I. Share of private hospitals in Germany and the United States, I980-20I0. Sources: Federal Statistical Office (www.destatis.de); Kaiser Foundation (www.statehealthfacts.org).

whereas the number of entrepreneurial providers delivering public goods for a profit has increased tremendously. In Germany, this trend has become most obvious in the health care sector: The share of for-profit hospitals has risen sharply over recent years. Today, the share of for-profit providers is even higher than in the liberal welfare regime of the United States (see Figure 1).

How can it be ensured that these private actors delivering public goods pursue socially desirable ends and neglect (or at least defer) self-interest? The traditional mechanism of accountability-hierarchical control-is stretched to its limits in welfare markets with autonomous private providers. Privatization, by definition, aims at "freeing organizations from the perceived burden of political control" (Bovens, 2005, p. 201). Scholars therefore argue that privatization leads to a decrease of accountability in terms of intensity and scope.

Organizational theories, however, have reminded us that organizations have to cope with strong normative expectations to adopt certain policies and practices in order to prove their public legitimacy (DiMaggio \& Powell, 
1983). This holds especially true for private actors delivering public goods as they depend on public resources. And accountability, again, is often said to be a mechanism that grants legitimacy in exchange for being controlled and overseen (Bovens, 2005).

Bringing the two perspectives of public administration research and organizational theory together, the present article enquires how accountability relations change when private for-profit providers become predominant in a policy field. Up to now, the literature on accountability has focused primarily on public organizations, analyzing, for instance, the difficulties of holding semiautonomous public agencies accountable. Against the background of the ongoing trend of privatization, however, the problem of making private actors publicly accountable has developed into a critical question. "[T]he continuing preoccupation of public administration with the accountability of public agencies seems, if not beside the point, at least to be missing a large part of the point" (Mulgan, 2000, p. 87). Moreover, thus far empirical application remains rare.

The present article wants to make a theoretical and an empirical contribution by exploring changing accountability mechanisms in the face of hospital privatization. The study is organized as follows: Reconstructing the previous research on accountability with a special focus on private sector accountability, we develop a theoretical framework that guides the analysis of accountability relations in welfare markets. We then apply this framework to the case of the German hospital market. Taking into account the different dimensions of accountability, we analyze corporate governance structures, legal and regulative initiatives, the instruments of quality assurance, the market and financial relations of hospitals, and reactions toward calls for public scrutiny. A special focus in the empirical section covers the new actors of accountability (those that call for accountability as well as those that may act as intermediaries), the conflicts that arise in light of growing accountabilities, and the state initiatives that try to hold hospitals accountable either in the traditional legal way or via new, dispersed modes of accountability (Hodge \& Coghill, 2007).

\section{Theory:Accountability-A Public Domain?}

Accountability is one of those political words almost everyone agrees with but hardly anyone knows what it exactly means. Fuzzily referring to a "more responsive" or "more democratic" political process or administration, accountability seems to be a mechanism that leads to a somehow "better" political performance. However, being applied to all kinds of different things, it remains unclear how far accountability differs from, say, responsibility or good governance. 
To empirically investigate accountability, we thus have to distinguish between accountability as a "political catchword" (Bovens, 2005, p. 184) and its meaning as "institutionalized practices of account giving" (Bovens, 2005; see also Bovens, 2010). The following chapter deals with the theoretical debate on accountability. It will be shown that some clear-cut conditions have to be met if we want to use accountability as an analytical concept.

\section{Accountability in the Public Sector}

Originally stemming from bookkeeping, accountability is nowadays only literally linked to accounting. Instead, it is said to describe a relationship in which an individual or agency (accountor) has to account for his or her conduct to another person or agency (accountee; Bovens, 2005). Five aspects turn a social relationship into a practice of accountability. Account giving is, first, a public action and not a discrete practice using informal channels of communication. Account giving means, second, providing explanations and reasons for the results of a certain conduct to an actor who has the rights of authority. Because accountability is characterized as a social interaction, these explanations may, third, be questioned and debated in a specific "forum", which functions as the locus of accountability relations. Account giving, fourth, does not depend on the voluntarism or the mood of the accountor; he or she rather feels obliged to explain himself or herself. Finally, the forum must possess effective means to either appreciate or to dislike and to sanction the actions of the accountor (Bovens, 2005).

This definition clarifies that the different instruments of public relations such as corporate social responsibility reports or advertisements cannot be considered as tools of accountability. Although they aim to explain and to justify the actions of an organization, they establish only one-way communication channels and do not qualify as being categorized as an accountability mechanism in the strict sense of this article.

\section{Accountability in the Private Sector}

Although accountability in the public sector has been broadly discussed, there is little research on accountability in the private sector. What are the distinctive features of private sector accountability and to what extent do these differ from those of public sector accountability? In addition to radical "free enterprise" positions that doubt that social and political stakeholders (or the public) have a general right to intervene into the realm of private economic action, there are the market-optimistic statements of public choice 
theory. According to this rigorous point of view, public accountability mechanisms are said to be typical for the public sector but superfluous in a market environment. Even more, pure market-based accountability mechanisms ${ }^{1}$ are considered to be superior to the tools of public accountability. The effects of competition and the possibility of investors and customers making use of the "exit option" ensure that management acts in the interest of the organization, putting aside its self-interest (Trebilcock \& Iacobucci, 2003, p. 205).

Markets, however, are not perfect. Especially in publicly traded stock companies, principal-agent problems are well known. In addition to the "exit" option (i.e., selling stocks), shareholders are warranted opportunities of "voice": They can hold management accountable by claiming annual reports and by asking questions at the annual general meeting. There is a long tradition of considering private companies as quasi-states and comparing the relations among management, the supervisory board, and the owners of the organization with those among the government, parliament, and citizens (Mulgan, 2000, p. 91). Similar to "public governance", "corporate governance" describes the division of power within a firm, namely, how are decisions made, what bodies are established, and who has to account to whom. Thus, the first approach to accountability in the private sector is to analyze the different types of corporate governance.

In doing so, one conspicuous difference between accountability in the public and in the private sector emerges. Although all citizens have the general right to call public organizations to account, the accountability of private sectors is restricted either to claims of individuals (e.g., from affected customers), which may be negotiated by private sector ombudsmen, or to shareholders enforcing their interests as owners of the company (Mulgan, 2000). Rights of authority are restricted to a small group even though corporate action affects a whole variety of issues, ranging from local residents to the wider public. ${ }^{2}$ One might thus state a severe lack of accountability in the private sector and claim that public accountability is a private responsibility (Leazes, 1997). While the broad effect of private economic action is one justification for calling private actors to account, the political-legal constitution of private entrepreneurship may be another. Because the state grants legal personality (with limited liability) to entrepreneurs expecting collective advantages from separating personal finances and business finances, it remains a political responsibility to control business action (Koenig-Archibugi, 2004).

Turning from the question of the accountability of private actors to the general public to accountability relations within an organization, there are similarities instead of differences between accountability in the public and in 
the private sector. Accountability relations within an organization, that is, the relationship between the apex of the organization and its members, have traditionally been understood as a downward chain of command and controlin the public as well as in the private sector. A firm is basically a hierarchy (Coase, 1937). But like in the public sector, it matters what kind of product an organization delivers. In the case of service deliverers such as hospitals, chains of command and control are questioned by professional accountability (Day \& Klein, 1987) — in a public as well as in a private hospital. Finally, in both sectors, the traditional understanding of internal accountability has been challenged by social developments and the notion of participatory governance. In the private sector, these processes have resulted in the ideas of codetermination and worker participation, which complement downward chains of command and control with mechanisms of upward accountability.

\section{Accountability in Hospital Sectors: Definition, Operationalization, and Data}

In accordance with Day and Klein (1987) and Bovens (2005), we understand accountability as a social relationship in which an actor feels obliged to explain and to justify his or her conduct to some significant other and where this significant other has effective means to reward or to sanction the actions of those who are held accountable. Accountability is a concept that is socially embedded. Building an analytical framework requires taking into consideration the historical, cultural, and institutional characteristics of the organization and the policy field under question (Day \& Klein, 1987). We want to contribute to this discussion by focusing on recent shifts in the institutional characteristics of the hospital sector, namely, the sharply rising number of private for-profit providers. Up to now, the question of the accountability of private actors delivering public goods has been neglected in research.

How do we operationalize the general definition of accountability to analyze accountability relations in the private hospital sector? Empirical research on accountability is about asking who has to account to whom for what. In this article, we are especially interested in the accountability of the hospital as an organization (in contrast to the accountability of a single doctor to his or her patients or of a nurse to his or her superior). We therefore examine to whom the hospital — or, to be more precise, the management board that is responsible for the governance of the organization - has to report. The group of accountees, that is, the actors who call private hospitals to account, consists of shareholders, politicians, administrative bodies, citizens, employees, and new intermediaries such as quality supervisory agencies. They hold hospitals 
accountable for various actions such as the use of financial resources, quality of services, or economic behavior.

The obligation of private hospitals to account for their actions can be distinguished into different types of accountability. In his seminal work, Bovens (2005) differentiated five types of accountability. Turning to private actors, however, requires complementing Bovens' classical framework with further dimensions, that is, including market and financial actors as well as the public and citizens (Hodge \& Coghill 2007, p. 680, Figure 2; see also Luke, 2010 for similar considerations but different labels; Moes, Berthoin Antal, Hofmann, \& Oppen, 2008). We therefore analytically distinguish eight different types of accountability; these are organizational, political, legal, administrative, professional, market, financial, and citizen accountability (see Table 1). ${ }^{3}$

Combining an analysis of these eight dimensions of accountability, we conduct a single-case study of the private segment of the German hospital sector. According to the literature on welfare regimes (Wendt, Frisina, \& Rothgang, 2009), the high proportion of private for-profit hospitals is untypical for the German corporatist welfare state. Focusing on the effects of privatization on accountability mechanisms, we thus analyze a salient phenomenon that is in need of investigation.

We draw on a mixture of primarily collected qualitative data and secondary sources. The former includes information on the formal corporate governance of the four biggest hospital chains (chapters on organizational and financial accountability), institutional arrangements and members of quality assurance boards (chapter on administrative accountability), and analyses of company reports (chapter on citizen accountability) and legal regulations (chapter on legal accountability). Data were collected via webpages, reports, and other publications of the organizations. The secondary sources consist of media coverage and scientific literature (chapters on market and professional accountability).

\section{Regulatory Architecture of the German Hospital System}

In discussing accountability in the German hospital sector, one has to bear in mind that this policy field features some special characteristics. Health governance in Germany can mainly be described by the notion of self-administration: Physicians and the representatives of both health insurances and hospitals are granted institutional rights, and thus, they are heavily involved in health policy. Although both the federal and the state governments provide a framework legislation, the implementation as well as the negotiations on details of 


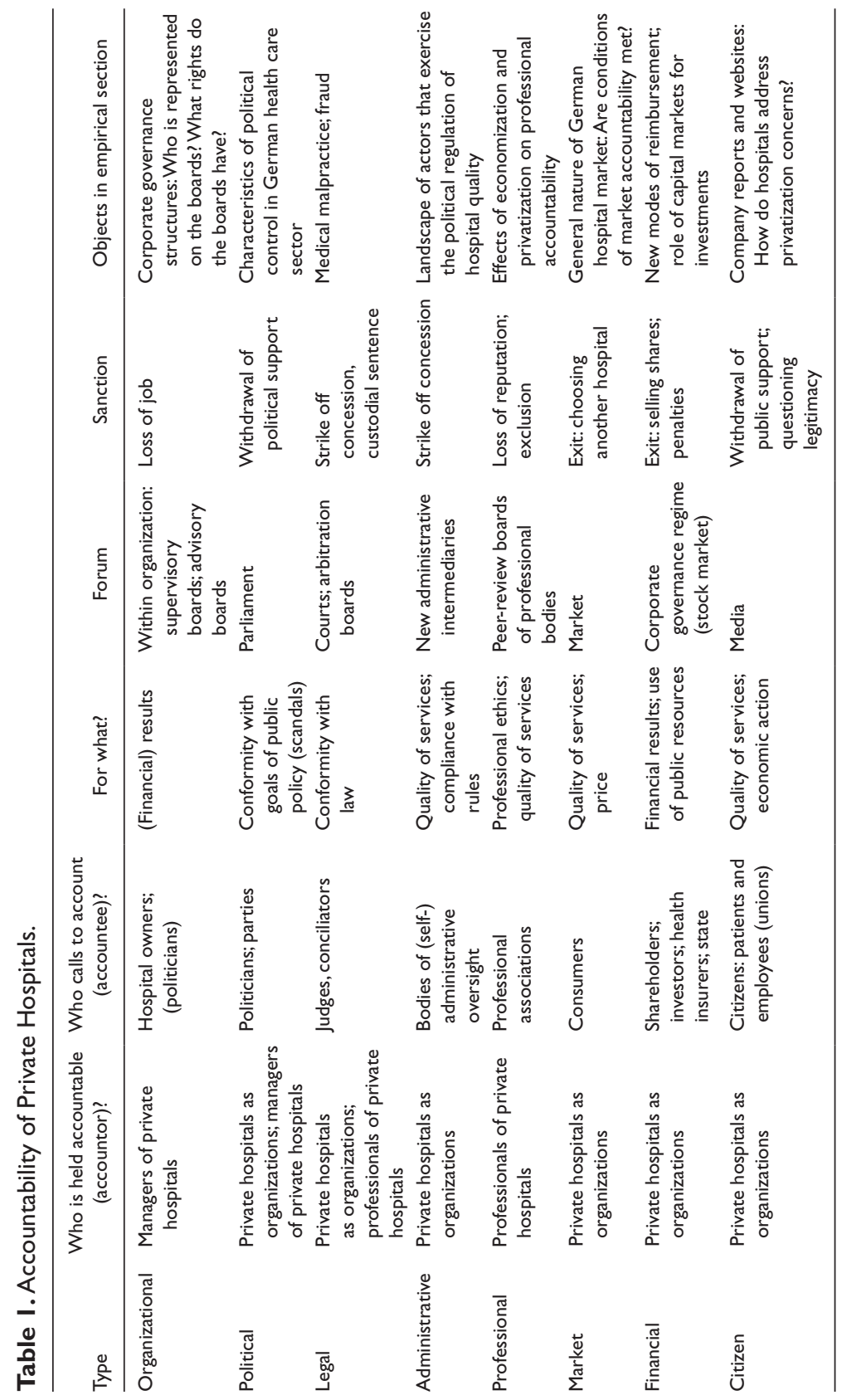


prices and offered services is left to the actors of self-administration with the Central Federal Association of the Health Insurance Funds, and the German Hospital Federation as the most important among them. The German Hospital Federation organizes public as well as nonprofit and for-profit hospitals, and the different ownership types have to agree upon common policies (Bode, 2010; Dent et al., 2004; Kuhlmann, 2006).

Steering at arm's length and semipublic actors operating in the "shadow of hierarchy" (Scharpf, 1997, pp. 195-215)—features that in other countries are a result of public management reform - have been known in Germany from the very beginning of health policy. Nonetheless public management reforms have had their impact on hospital governance in Germany. Already since the 1980s, and with an accelerated tempo since the 1990s, several hospital reforms have restructured both the funding system and the organization of work with the aim to increase efficiency and cost control in times of financial austerity.

Hospital funding in Germany is based on a two-pillar system with the operating costs paid by the health insurances and the investment costs paid by the states. Hospitals accredited in public hospital plans, meaning that they are considered to be necessary to provide equal and nationwide access to hospital care, are eligible for public funds - irrespective of their ownership type. This so-called "dual funding system" has undergone profound changes, especially with regard to funding provided by the health insurances. In several reform steps, the former full cost coverage principle has been replaced by a prospective diagnostic-related group (DRG)-based payment system. However, the reorganization in the wake of the introduction of DRGs goes far beyond a mere change of payment practices: It has pressed ahead the managerialization of internal hospital governance. The DRG system has contributed to an increase in administrative complexity as it requires a developed information system documenting detailed information on diagnosis, treatments, duration of stays, and so forth (Mosebach, 2009).

Apart from the restructuring of internal hospital governance, the introduction of DRGs has had also a strong impact on the ownership structure in the German hospital sector. The abolishment of the full cost coverage principle has especially affected public hospitals. Against the backdrop of already empty coffers, many local communities and cities could no longer afford to subsidize their hospitals after the shift to the DRG system. They welcomed private for-profit providers, who have access to the capital market, to overtake their indebted hospitals. While in $199114.8 \%$ of hospitals were run by private owners, this share reached 33.2\% in 2010 (Statistisches Bundesamt, 2011). This is especially striking when compared with the United States, a 
health care system that has been described as liberal, that is, relying on privately financed and privately provided welfare. Figure 1 shows that private hospitals have been on the rise in both countries, Germany and the United States. However, the relative growth of private hospitals has been much stronger in the corporatist welfare state. ${ }^{4}$

To sum up this sketch on the dynamics of a changing hospital governance in Germany, one could ascertain both an increased managerialization of internal hospital governance and a marketization of the hospital sector. Due to augmented cost pressure and increased competition, hospitals irrespective of the ownership type are forced to operate in a business-like manner (Bode, 2010). Managerialism and marketization, however, have not replaced former modes of self-administration. Rather, they have put a new layer on an already hybrid governance structure. Although the process of hybridization is well described in recent literature, it is mainly neglected what impact hybridization has on accountability, especially when it comes to the accountability of private for-profit providers (for public and voluntary providers, see Mattei, 2009). How does the intrusion of private for-profit providers affect existing accountability relations? Are traditional accountability relations replaced by market mechanisms? The subsequent paragraphs analyze accountability relations in the German hospital sector by highlighting the changes that have taken place in the light of privatization.

\section{Empirical Findings: Accountability Relations of Private Hospitals in Germany}

\section{Organizational Accountability}

In private corporations, organizational accountability - accountability within an organization - is defined by the rules of corporate governance. These describe the ways business corporations are directed and controlled and how rights and responsibilities are distributed among different participants in the corporation. Organizational accountability is of special importance when there is a separation of management from ownership. In this case, typical principal-agent questions arise such as "How can we ensure that management acts in accordance with the interests of the owners?". Supervisory boards with representatives of the owners are established to control management. Apart from the control of management by the owners, employee participation is an issue of corporate governance, especially in countries with a strong corporatist tradition such as Germany. According to the law on codetermination, German companies with a workforce of more than 2,000 employees are 
obliged to introduce participative corporate governance structures. The general principle is to have parity between employee and shareholder representatives on the supervisory board. The management board, which leads the company, is elected by the supervisory board, and it can be held accountable by representatives of both the owners and the employees.

Corporate governance depends, first, on legal requirements - each legal form has its own board structure and distribution of organizational power. Corporate governance, second, depends on organizational culture as our case study clearly shows. Of the four most important private hospitals in Germany-Helios GmbH, Asklepios GmbH, Sana Kliniken AG, and RhönKlinikum AG - the latter, in particular, goes beyond legal requirements with regard to publicness.

Rhön-Klinikum AG is a publicly traded stock company. In terms of corporate governance, this company differs considerably from its competitors. The company has three boards: a management board, a supervisory board, and an advisory board. The supervisory board consists of 20 members; according to the law on codetermination, half of them are representatives of the shareholders, whereas the other half are representatives of the employees and their unions. Rhön-Klinikum AG grants "high priority to good corporate governance" (Rhön-Klinikum AG, 2010, p. 40). To strengthen the trust shareholders place in the company, the company binds itself to a transparent management of the risks and opportunities in the interests of both the shareholders and the employees - at least according to its declaration of corporate governance pursuant to the German commercial code (RhönKlinikum AG, 2011).

In addition to the management board and the supervisory board, RhönKlinikum AG has an (not legally required) advisory board. Its 11 members advise the management board with regard to important trends in the health care sector. Most of the members are scientists with either an economic or a medical background. Rhön-Klinikum AG, however, also places value on having actors on the board who will shape the future development of the health care sector, namely, representatives from the political and administrative realm.

Sana Kliniken AG is a stock company, too. Yet, its stocks are not publicly traded. It is owned by 31 private health insurance companies, and it has a twotier governance structure with a management board and a supervisory board. Sana Kliniken AG is subject to the German law on codetermination, and the representatives of the employees participate on the supervisory board.

Helios and Asklepios are companies with limited liabilities. While Helios $\mathrm{GmbH}$ has a two-tier governance structure, Asklepios has 
only a management board. Upward accountability relations, for example, the possibilities of employees holding management accountable for human relations management, are comparatively weak in this company. After having bought the public hospitals of the German state Hamburg, worker participation in these hospitals has been reduced to the legally required minimum (Breiholz, 2008). In contrast to its competitors, statements in favor of participative corporate governance are hardly found on the company's home page.

As this brief look at corporate governance structures has shown, the mechanisms of organizational accountability differ across companies in at least two respects: the integration of employees and political stakeholders. An advisory board that establishes a relation with the wider public is a special feature of Rhön-Klinikum AG-none of the other three companies allows public representatives (as delegated by the public administration and/or state parliaments/local councils) to participate in corporate governance. Yet, the advisory board of Rhön-Klinikum AG has no rights at all to hold management accountable. It can give advice but not impose sanctions.

\section{Legal Accountability}

The important issues of legal accountability in hospital governance are medical malpractice and financial fraud. The question under discussion is whether the increased share of for-profit providers influences the likelihood of false claims and malpractice. Indeed, the intrusion of the for-profit motive into the health care sector has been a source of concern in this respect. For example, does the organizational character of a for-profit provider affect adherence to medical ethics to the degree that treatments considered necessary but too costly (or not covered by health insurance) are denied? Is the workload so high that mistakes are likely to increase? Are doctors even encouraged to bill for treatment they never provided?

In line with the general idea of health governance in Germany, namely, self-administration, conflicts concerning (supposed) malpractice are regulated by extrajuridical mechanisms based on the idea of self-regulation. The loci of accountability are expert commissions or arbitrary boards; courts are only considered as an ultimate settlement of a dispute, when conflict solving by voluntary arbitration cannot be reached. Arbitration as a conflict-solving mechanism was introduced in the mid-1970s. What brought the establishment of these new institutions about was the sharply rising number of lawsuits concerning malpractice at this time. Doctors took on the initiative of establishing these new institutions of conflict management. Fearing professional as well as economic disadvantages from standing publicly accused at courts, they voted for conflict-solving mechanisms based on self-regulation (Meuerer, 2008). 
Today, there are nine arbitrary boards located within the medical associations. These boards consist of physicians and judges. In the event of a conflict, all parties involved - patients as well as doctors and health insurers - have the right to ask for an impartial adjudicator to review their cases before or instead of going to court. This medical arbitration is free of charge for all parties involved; furthermore, participation is voluntary, and the results are nonbinding. About $25 \%$ of all conflicts concerning malpractice are heard by an arbitration board (Bundesärztekammer, 2010).

The number of conflicts has been steadily rising over recent years. ${ }^{5}$ Yet, the statistics neither conclude that malpractice is a question of ownership nor suggest that we are moving from a period in which physicians' accountability to patients was handled well to one in which it is not (Gray, 1991). The higher intensity of conflicts between patients and their doctors cannot be explained as a negative externality of a for-profit health care industry. The literature rather agrees that the rising number of conflicts is a result of increased patient emancipation (Meuerer, 2008).

Fraud, the second issue of legal accountability, is a hot topic in Germany every now and then. In spring 2010, the National Association of Statutory Health Insurance Funds (Spitzenverband Bund der Krankenkassen), the lobby of the statutory health insurance funds in Germany, accused hospitals of systematically submitting false claims (Medizinischer Dienst der Krankenversicherung [MDK] Gemeinschaft, 2010). Only a year later, in April 2011, the Federal Court of Audit criticized the possibility of systematic health care fraud, which quickly gained public attention. The mass media rapidly seized on the issue, kicking off a campaign and reproaching hospitals of committing fraud on the charge of the collective body of the insured. More effective accountability mechanisms were requested.

Controlling the accounting practices of hospitals belongs to the field of responsibility of the Medical Service of the Health Insurance Funds ([MDK]), an independent agency financed by statutory health insurance funds. The MDK controls the necessity and the duration of inpatient care $(\S 275$ SGB [Sozialgesetzbuch Code of Social Law] V; § 17c KHG [Krankenhausfinanzierungsgesetz - Federal Law on Hospital Funding]). If the suspicion of having submitted false bills is proven wrong, the health insurance funds have to pay 300 Euros to the hospital to compensate it for the administrative expenses borne out of these additional accounting controls. If a hospital is found guilty, the lacking sum has to be paid. However, no additional fine or other sanctioning instrument is applied. Thus, critics assess the accountability mechanisms as too weak to prevent fraud. Generally, health care fraud is - even more than medical malpractice - treated in the public discussion as a problem of ownership: The for-profit motive is considered to be the main trigger of health care fraud. 
Empirical evidence that financial fraud is primarily committed by for-profit providers, however, remains sketchy. Controls in the German hospital sector have revealed that voluntary as well as private for-profit providers have submitted false claims. The most spectacular cases, which have been intensively debated in the media (e.g., Bach \& Kneist, 2011), were the hospitals of the Red Cross in Germany, a private not-for-profit welfare association, and of Helios, one of the four biggest private for-profit providers in Germany.

In summary, we conclude that legal accountability is an issue in the German hospital sector. Medical malpractice and health care fraud, however, are not a problem related to for-profit hospitals alone. Rather, it seems that the economization of the health care sector has negative effects on all types of hospitals. Regardless of the type of ownership, hospitals are under strong pressure to perform well financially, and therefore, they are likely to commit fraud (for similar developments, see the U.S. experience, Gray, 1991).

\section{Political Accountability}

Direct accountability relations between private hospital managers and politicians are limited for three reasons. First, while mechanisms of political accountability are common, for instance in the U.S. presidential system, where senior public managers have to report before parliament, and alsoalthough in a much more informal way-in France or in Belgium (Bovens, 2005), in Germany - with its strong belief in ministerial responsibilitypolitical accountability plays only a minor role. Second, the negligible role of political accountability is especially true for the administration of the health care sector. Not least for the reason of blame avoidance, major responsibilities for health care administration have been shifted from parliament to semipublic corporatist actors such as the Federal Joint Committee (Gemeinsamer Bundesausschuss [G-BA]). Instead of parliament, the G-BA and other bodies of the so-called system of self-administration call health care providers to account. Finally, the direct political control of corporate action is limited because private hospitals are regulated by private law. Unlike public managers, private hospital employees do not have to account to elected representatives and political parties. Yet, there may be one exception to this rule: Companies may decide to appoint politicians as members of their company boards either in a supervisory role or as advisors. However, as the section on organizational accountability has shown, this is rarely the case.

Privatization can be interpreted as a political strategy to avoid responsibility for the declining quantity and quality of hospital services. In light of the increasing role of private actors, anonymous market processes can be 
blamed for the outcomes of hospital sector transformations. Unlike in public hospitals, where politicians often function as chairpersons of advisory boards, there are no such political roles in private hospitals and accordingly no such political responsibilities. Empirical evidence on how politicians treat possible misbehavior by private hospitals is not yet available. One might, however, assume that public goods, such as hospital services, remain a political responsibility in the case of market failure respectively the failure of individual market actors. This could, in turn, cause political claims for private hospital accountability, changing the relationship between political bodies and hospital companies.

\section{Administrative Accountability}

Apart from legal supervision ${ }^{6}$ and the regulation of competition, politicaladministrative intervention in hospital sectors is mainly about setting standards of quality assurance. It is a means of holding hospitals accountable for the most crucial part of their activities: the treatment of patients. Traditionally left to professional self-governance bodies, quality assurance has been an issue of federal health policy since the late 1980s. Today, five mechanisms are applied to every hospital, while regulations at the state level may complement these standards: external quality comparisons, internal processes of quality management, publication of quality reports, minimum numbers of treatments for special therapies or operations, and structural adjustments such as special treatment of just-born babies or specialized centers for children with cancer. Although the general implementation of these measures is legally binding, self-administration remains responsible for the precise definition of quality assurance instruments.

Quality regulation at the federal level has intensified since 2000. During this time, not only has state intervention become more dominant but also the organizations of quality assurance has been delegated to newly emerging actors, and among them certification and accreditation agencies. Apparently, there has been a parallel rise in the number of private hospitals and quality regulation. In the same period, as quality regulation has increased, private hospitals have expanded their overall market share at the expense of public ownership (see Figure 1). Although the parallelism is striking, the debate on quality assurance in the German hospital sector seems to be independent of these changing ownership figures. When passing the bill that fundamentally changed quality regulations, ${ }^{7}$ the argumentation in parliament was not about the different types of hospital ownership but rather about the federal harmonization of different state-level rules. 
Quality assurance, therefore, cannot be considered as a direct response to the increased share of private for-profit providers. We observe, however, an additional trend that suggests that quality assurance changes in light of a more and more marketized hospital sector: Private hospitals have recently started to act as pioneers of privately initiated quality comparison. Of the two relevant initiatives, the most recent is called Qualitätskliniken (quality hospitals). It is available online and officially aims at promoting the German health system by publishing quality indicators. It was founded in 2010 by three of the four biggest hospital chains in Germany (Asklepios Kliniken, Rhön-Klinikum, and Sana Kliniken), and it claims to be the most comprehensive system in terms of information and transparency in the German hospital sector. ${ }^{8}$

Although it was founded by private hospitals, voluntary as well as public hospitals are invited to join the comparison as well as to collaborate in the organization's bodies. Members are represented on a board that comprises 11 representatives in total: three from each type of provider plus two from university hospitals. Consequently, there is an internal differentiation between hospital types. Members are classified as private, public, voluntary, or university hospital, and these groups vote for their representatives in separate elections. In June 2011, there were 154 members of whom 79\% were private hospitals (compared with $17 \%$ public and $5 \%$ voluntary hospitals). ${ }^{9}$

The introduction of Qualitätskliniken is closely linked to the privatization trend in the hospital sector. Considering theories of private sector accountability, the disclosure of quality indicators is likely to be initiated by private actors. Private firms are expected to disclose information about their services because the markets ask them not only to prove success but also to use such information as a competitive tool (Trebilcock \& Iacobucci, 2003). Since hospitals only benefit from quality if they are able to present their results to the wider public, the communicative function of Qualitätskliniken is a precondition of competition. The communication of quality results corresponds with consumers' abilities to choose: Only informed patients can act as sovereign consumers, improving competition within the hospital market when making use of their "exit" option. Qualitätskliniken can thus be seen as an instrument that potentially (if other conditions were fulfilled) strengthens competition in the hospital sector. ${ }^{10}$

What effect does the establishment of such systems of voluntary quality comparison have on accountability relations? Obviously, the intention of the founders is to improve accountability relations. Launching Qualitätskliniken, Roland Dankwardt, medical director of Asklepios, stated, "It is time for hospitals to report on their own, not to be the object of reports from external 
actors. This kind of accountability should cover more than a small segment and should be recognized by many hospitals" (Sana Kliniken AG, 2010, own translation). As this quote reveals, such initiatives are an answer to the increased political intervention into hospital regulations and the rise of intermediary actors. It is thus an attempt to restrain political activity in this field. Establishing private systems of quality assurance should prevent further political calls for accountability.

Against the expectation of weakened accountability relations in privatized sectors, we find private initiatives that go beyond legally required administrative accountability. Although it remains an incomplete accountability mechanism in many respects (the account giving is rather undirected, recipients of quality disclosure have no right of authority, participation in quality comparison is voluntary, and hospitals do not feel obliged to explain), the comparative quality disclosure of Qualitätskliniken is a hint that private providers of public goods feel a need to justify their actions and results. Assuming that Qualitätskliniken mimics accountability mechanisms, we hypothesize that entrepreneurial actors in welfare markets try to behave like public or nonprofit actors. Rather than abandoning accountability mechanisms, they become active themselves. We expect private hospitals - among other factors such as competition, as argued above - to mimic accountability mechanisms because they profit from one of the benefits of accountability: organizational legitimacy. Accountability is usually said to be a source of legitimacy because transparent chains of control and responsive organizations generate more confidence in the actions of public administrations as well as of private actors (Aucoin \& Heintzman, 2000).

\section{Professional Accountability}

Professional responsibility is a crucial dimension of internal hospital accountability. Traditionally, physicians have been at the center of hospitals' decisionmaking systems, and hospital governance was based on professional self-regulation. The ideas of the new public management movement, however, have also had their impact on the internal governance of hospitals. Practice guidelines, evidence-based decision making, or performance measurement have been introduced to rationalize hospital management. Professional accountability based on knowledge and expertise is challenged by managerialized mechanisms of accountability, namely, clearly defined standards of care and output control with quantitative, thus "objective", criteria.

Political initiative has been a driving force behind this transformation of professional accountability. These newly introduced modes of hospital 
governance are primarily thought to provide the state - the main funder of hospital care - with information to control spiraling costs (Tuohy, 2003). Second, they are meant to control professionals to improve their accountability toward patients. In the literature, however, the impact of managerialism on the work of professionals is contested: Although one strand of the literature states a deprofessionalization of medical and care work as doctors and nurses spend more and more time on administrative duties at the expense of their time for the treatment of patients, others argue that especially doctors are not passively responding to demands for management. Kuhlmann and Burau (2008) pointed out that professionals play an entrepreneurial role and are heavily involved in developing the new governance structures. Medical research provides evidence-based knowledge, which subsequently is spread out through the community through the self-governing bodies of the medical professions (see also Kirkpatrick, Jespersen, \& Dent, 2009). Thus, what surely can be stated is a transformation of medical power as the patterns of legitimate knowledge change. It is, however, another question whether physicians have been made more answerable. The transformation of professional accountability by no means implies that medical power has become a publicly monitored arena (Kuhlmann \& Burau, 2008).

\section{Market Accountability}

Proponents of markets assume that customer power is an effective substitute for traditional accountability because corporate misbehavior will be punished by customers choosing the exit option (Trebilcock \& Iacobucci, 2003). The interplay of supply and demand is expected to make market actors more responsive to the needs of customers. Market accountability assumes that there is competition between market providers, which allows individuals to act as sovereign consumers. We thus ask how far the hospital sector in Germany meets the conditions of an effective market, focusing on the supply of hospital services as well as on patients as demanders.

In Germany, there is an ongoing juridical as well as scholarly discussion on whether the competition law applies to the hospital sector or not. The subject of the controversial discussion is whether there is an effective hospital market given the fact that inpatient care is highly regulated by the principle of solidarity, namely, do hospitals compete for patients at all? ${ }^{11}$ On one hand, the federal competition authority (Bundeskartellamt, 2005) has recurrently argued for the existence of a hospital market when reviewing corporate mergers of hospitals. For instance, individual prohibitions of mergers have been justified by the negative effects that they would have on competition in 
the hospital market. Because there is an overcapacity of beds, hospitals are said to compete for patients who sovereignly choose which hospital best suits their needs (e.g., Bundeskartellamt, 2005).

On the other hand, the analysis of the competition among suppliers reveals some structures that fundamentally contradict the diagnosis of a competitive hospital market. Generally, in markets, suppliers compete for customers using different parameters of competition, among them and most crucial are price and quality. In the German hospital market, price competition is prevented because of the politically determined flat rate payments. Moreover, the range of services provided is fixed by law. Contrary to regular businesses, hospitals can change neither their services nor the prices of their services according to economic calculations. Finally, competition on quality is limited because of the professional ethics of doctors. Businesses usually keep technological or management progress private to benefit from competitive advantages. Doctors, however, are committed to the health of all potential patients. Keeping quality progress a secret would thus contradict the professional ethics of doctors. The quality advantages of individual hospitals will thus only last for short periods of time (Bruckenberger, Klaue, \& Schwintowski, 2006).

However, what about the demanders of hospital services? Do they act as sovereign market participants? Generally, markets require sovereign customers who are able to assess the quality of goods and services and use the "exit" option in case of unsatisfying results. In the health care sector, only a small proportion of patients chooses the hospital, whereas the majority is hospitalized either because of an emergency or by general practitioners/ registered doctors. The influence of patients is thus limited. Even if one assumes an individual freedom of choice, a hospital customer would need to meet the same conditions that may be realistic for a small group of patients but are unlikely for the majority. Because the demand for hospital services is irregular and unpredictable, that is, demand occurs only in the case of illness, patients would not only need to be spatially mobile but there would need to be enough time between diagnosis and treatment to collect market information and to choose the right hospital (Arrow, 1963).

To sum up, the conditions of effective markets are not met in the provision of hospital services. Whereas markets often suffer from imperfect conditions, this holds especially true for hospital markets. On both sides - hospitals as providers, patients as demanders - no real market coniditions are given. Considering the lack of individual hospital choice and missing competition between hospitals, up until now, market accountability has not been a relevant mechanism in the German hospital sector. Patients thus have to rely on other mechanisms than "exit" to hold hospitals accountable. 


\section{Financial Accountability}

Financial accountability refers to those actors who provide financial resources holding the producers of goods and services to account. Unlike consumers who are said to seek a relation between price and quality, financial accountees call for a return on investment (or, as we will see in the case of hospitals, for service outcomes). In the private sector, financial accountability relations typically exist between companies and investors. Rating agencies may act as intermediaries. Shifting the focus to the welfare state, public authorities come in as the financers of public goods and services. In the case of private hospitals, statutory health insurance funds play a role as the financers of services, whereas private money becomes increasingly important for investments into hospital buildings and technology. Analyzing recent changes in the financial accountability of private hospitals, we focus on the introduction of new modes of hospital service funding (i.e., the introduction of DRGs and the increasing role of financial markets in hospital investment).

Since the mid-1990s, the reimbursement of hospital services has been transformed from the full cost coverage principle to a system that is based on case fees, finally leading to the introduction of flat rate payments in 2004 (DRGs). The specification of these flat rates is the responsibility of the actors of self-administration; based on politically enforced self-regulation, the exact levels of flat rates are negotiated between hospital providers and health insurance funds.

Again, as outlined in the section on legal accountability, we find the idea of arbitration to be a mechanism that ensures accountability and solves conflicts. If hospitals and insurance providers cannot come to an agreement on flat rates, they appoint an arbitration board that consists of the association of each interested party and a neutral chairperson ( $\$ 18 \mathrm{a} \mathrm{KHG})$. Yet, regarding the interaction with health insurance funds, there is no information on the differences between hospital providers. Thus far, the inner lives of arbitration boards have remained a black box. We thus cannot assess whether private hospitals behave differently compared with public or voluntary providers. ${ }^{12}$

Although health insurance funds pay for hospital services, long-term investments are traditionally financed by the Länder. However, there is a massive backlog of public investment into the hospital sector (Penter, Arnold, Eifler, \& Friedrich, 2009). Bidding for the takeover of public hospitals, private providers often announce investments into hospital buildings. These investments may persuade public owners, and, at the same time, they are a precondition of productivity gains because internal processes of private hospitals are often optimized by constructional changes. As far as private 
investments are concerned, for-profit hospitals benefit from better access to capital markets. This is when a new type of financial accountability gains in importance in the hospital sector. Financial investors provide hospitals with resources but expect a return on their investment. The accountability relation between hospitals and financial investors is market based. Rating agencies act as intermediaries, thereby enhancing or worsening the chances of hospitals to attract capital. Orientation toward new sources of finance differs across the four biggest private hospital providers in Germany. Having been listed since the late 1980s, Rhön-Klinikum AG is a forerunner as a publicly traded company in the German hospital sector. Helios is owned by the MDax-listed health care group, Fresenius, linking it indirectly to the stock market. On the contrary, the shares of Sana Kliniken AG are not publicly traded but are constantly held by 31 German health insurance funds. Market leader Asklepios is a company with limited liability, which in 2010 started to issue bonds. Yet, capital market orientation remains low. ${ }^{13}$

This short overview provides a first impression of the different levels of capital market orientation of private hospitals. Differences across companies not only depend on the legal forms but also on the historical developments of companies. Sana, for instance, was founded by private health insurance funds to prove the ability and success of private economic action in the hospital sector. Regardless of any differences across private hospitals, compared with public and voluntary hospitals, private providers can tap the sources of capital markets more easily. This has become an important advantage of private hospitals in light of state budget crises. Accordingly, financial accountability will transform in parallel with the privatization of the hospital sector. Following the introduction of a new reimbursement system (DRGs), which is said to foster economization, there has been a rise in the number of financial investors that, for instance, engage in the funding of hospital buildings, thereby replacing the state as the traditional investor in hospitals.

\section{Citizen Accountability}

Being accountable to citizens - or the wider public - is becoming increasingly important to all kinds of organizations. This holds especially true for private hospitals because they operate in attentively monitored markets. As they provide public services, they are subject to calls for public scrutiny that differ from those of other private branches. Although corporations must disclose information only to a limited extent, ${ }^{14}$ private actors in public services are called to meet a variety of political and social expectations, forcing them to be much more transparent and accountable. 
In Germany, hospital privatization often faces enormous public protest. Both citizens and unions usually try to stop the selling of public hospitals to private owners as they fear either a reduction in quality because of efficiency constraints or redundancies (Böhlke, Gerlinger, Mosebach, Schmucker, \& Schulten, 2009). Although these protests originally aim at preventing privatization, they may also act as watchdogs of already privatized hospitals. Corporate private actors thus become subject to public scrutiny.

As an example of such public supervision, the website www.rhoenwatch. de was founded by the multiservice trade union "ver.di" in the aftermath of the privatization of the university hospital Gießen Marburg. The patients and employees of the private hospital Rhön-Kliniken were asked to report on any experience with the hospital (Coordes, 2008). ${ }^{15}$ Today, the homepage does not exist anymore after ver.di in 2008 decided to go offline with the site for strategic reasons. Although "Rhoenwatch" lacked the right of authority and could not call any responsible manager of the company to account, the call for scrutiny was closely related to claims for accountability. Trying to make private hospitals answerable to citizens is obviously a reaction to accountability deficits in the private sector.

Against this background of a partially hostile public that calls for accountability, how do private hospitals respond to public protests? Do they answer the concerns of citizens, employees, and local politicians? And do they contribute to the establishment of new accountability relationships? Assessing the company reports of the four largest private hospital chains between 2001 and 2009 and those parts of their hospital websites that deal with privatization, we analyzed how, if at all, private hospitals address privatization concerns. Generally, privatization (and public concern linked to privatization) is rarely mentioned in annual reports or on company home pages. Less than $1 \%$ of annual report pages deal with privatization. Although there was a slight increase in the average volume of privatization sections between the early $2000 \mathrm{~s}^{16}$ and 2009 , the big four German hospital companies regularly neglect this topic within annual reports. However, there are differences across companies. While Asklepios does not address privatization at all, the 2009 report of Rhön explicitly deals with privatization concerns. The 2009 reports of Sana and Helios also have their own privatization sections, which are limited to one or two pages. All four corporations discuss privatization on their webpages. ${ }^{17}$ Interestingly, Rhön again most extensively deals with privatization, whereas its three competitors uphold their shorter sections.

Going beyond the volume of privatization sections, a qualitative analysis of reports and websites reveals that hospitals address privatization in different contexts. Actors who are addressed by these sections range from investors 
and the public owners of hospitals to citizens and employees. Considering the original function of annual reports, corporations, not surprisingly, discuss the economic aspects and chances of privatization, such as the different models of investment, technical requirements of privatizations, and legal forms. The concerns of the society are dealt with by using the following:

- portraits and quotes of citizens that report on their excellent experiences with privatized hospitals (Rhön);

- interviews with a CEO about sustainable corporate behavior (Sana);

- descriptions of the privatization process, namely, the interplay between public administration and private corporations (Helios); and

- announcements that privatized hospitals will not cut jobs and will maintain the existing structures of regional hospital provision (Asklepios).

Overall, the analysis of privatization sections in annual reports and on corporation websites confirms the assumption that accountability relations are multiplying. Private hospitals are accountable to multiple legitimate masters, including investors, citizens or patients, employees, and local political authorities that own public hospitals and that may wonder if and how privatization would be an option.

According to our findings, corporate disclosure does not seem to change in the face of public concerns, especially those of unions and patients. Even those parts of annual reports that address the concerns of a "privatizationunfriendly" public can better be described as public relations than as a step toward citizen accountability. While accountability is said to deliver an explanation or justification of corporate action (Bovens, 2005), annual reports simply advertise the company, promoting its superior quality compared with other hospitals. Summing up, claims for the citizen accountability of privatized hospitals have increasingly been raised. Yet, effective citizen accountability remains incomplete.

\section{Discussion: Freed From the Burden of Public Control? Private Actors and Accountability}

By analyzing the accountability relations of private for-profit providers delivering public goods, the aims of this article were to contribute to the theoretical debate on private sector accountability and to empirically study the major trend in the German inpatient sector: privatization.

What can we conclude? The mainstream of the literature argues that privatization implies a sacrifice of accountability. Privatization basically aims at 
making organizations more independent of external regulation, and, therefore, it comes along with a loss of accountability. This study, however, has shown that the predominant assumption of an "accountability gap" is much too undifferentiated not only because the private sector has its own accountability mechanisms, which have been neglected in the recent public administration literature, but also because private for-profit providers go beyond the legal requirements and introduce new instruments mimicking accountability mechanisms. We observed three trends with regard to the accountability of private actors delivering public goods:

1. There are different modes of account giving. Privatization increases market-based accountability because control over corporate action is exercised through corporate governance or consumer relations. Unlike traditional modes of accountability, market-based mechanisms are built on the implicit threat of "exit". They systematically differ from more "deliberative" forms because the phase of debate is reduced to a shorter period of time, and there is less coordination between the actors. Market-based accountability emphasizes accountability for outputs, neglecting thereby the importance of due processes on the input side and the accountability within organizations. Indeed, the shift to market-based accountability mechanisms threatens both the value of professionalism in hospital governance and working conditions for staff. In particular, public choice approaches that expect markets to make up for traditional accountability mechanisms (e.g., Trebilcock \& Iacobucci, 2003) might underestimate noninstrumental values.

2. Private actors become active themselves. However, the accountability mechanisms of private hospitals are often incomplete. One has to carefully distinguish between accountability as a social relation and "one-way accountabilities". Some of the phenomena found during this research are closely linked to the question of accountability. Yet, they remain unsatisfactory answers to a lack of accountability. On one hand, a partially hostile public calling private hospitals to account for their actions has no rights of authority because these claims have not yet been transformed into institutionalized practices. On the other hand, institutional innovations such as Qualitätskliniken provide only one-way communication channels rather than establishing a forum for debate and judgment with respective means of reward and sanction. 
Incomplete accountabilities may either be a first step toward the establishment of institutionalized accountability relations or remain a mere simulation of accountability. Organizations might be interested in the simulation of accountability to benefit from the effects of accountability (i.e., legitimacy). Although attempts to establish encompassing accountability relations are more likely to be introduced by potential accountees, initiative to accountability simulation is more likely to come from accountors.

3. In summary, accountability is not decreasing but multiplying. Rather than stating a gap of accountability, the recent situation is better described as a transformation into an "age of many accountabilities" (Moes et al., 2008, pp. 47-50). Instruments that aim at improving accountability are abundantly in place, and hospitals are located in a net of accountability relations. With the hybridization of hospital governance (Kuhlmann, 2006), the number of actors calling hospitals to account is also increasing. New intermediaries have been established in the hospital sector, and these have gained relevance especially for private for-profit providers, namely, financial investors and rating agencies.

Sure enough, it is necessary to remember that reporting to "many eyes" does not automatically imply increasing compliance with public interest. Neither supervisory boards nor financial investors represent public interests. Privatization leads to decreasing political control. A government that considers accessible and high-quality inpatient care important, has to, therefore, set up alternative accountability mechanisms. The section on administrative accountability has shown that a first step has been carried out with the establishment of (semi)independent agencies calling hospitals to account for the quality of their services. Yet, up to now, there has been a lack of empirical data to assess the effectiveness of these accountability mechanisms and to analyze whether for-profit and nonprofit hospitals respond differently to these claims.

What does the German case contribute for an international debate? For our analysis of accountability relations in a marketized welfare sector, we have complemented Boven's classical analytical framework with the dimensions of market, financial, and citizen accountability. In doing so, we traced shifts in the locus and content of accountability claims. This finding is true not only for the German hospital sector but also for all countries that experience an economization of the hospital sector, that is, every country in the western 
world. If multiplication of accountability relations can be observed in corporatist health care systems such as Germany, a most unlikely case for the rise of for-profit providers, we would expect to find much stronger effects of accountability dispersion in a liberal health care state like, for instance, the United States.

Overall, the study has revealed that accountability aspects that are normally ascribed to private providers (e.g., financial fraud, capital market orientation, or competitive quality comparison) are today also an issue in the voluntary and the public sector. The economization of hospital sectors has left its mark: Against the background of severe budget problems, not-forprofit hospitals are, for instance, just as likely to submit false claims as are for-profit providers. Furthermore, similar to for-profit providers, not-forprofit providers depend on private investment to modernize (or just maintain) their infrastructures. An "age of many accountabilities" (Moes et al., 2008, pp. 47-50) has begun for all types of hospital providers.

This development raises new questions such as how can hospitals cope with the "problem of the many eyes" (Bovens, 2005, p. 186). Hospitals have to justify different aspects of their organizational behavior in different forums. It can easily be imagined that different claims for accountability might contradict and result in organizational stress. The question is how hospitals cope with multiple and conflicting external requirements-by "decoupling", namely, by creating and maintaining gaps between formal policies and actual organizational practices, as institutional theory suggests (Meyer \& Rowan, 1977)? Further research is needed to answer these questions.

\section{Declaration of Conflicting Interests}

The author(s) declared no potential conflicts of interest with respect to the research, authorship, and/or publication of this article.

\section{Funding}

The author(s) received no financial support for the research, authorship, and/or publication of this article.

\section{Notes}

1. Note that market accountability is not the same as market-based accountability. We define market accountability as a relationship between private hospitals (as accountors) and patients or customers (as accountees). The term market-based accountability refers to how accountability is mediated. Obviously, market accountability can be one type of market-based mechanisms but is not the only type (see, for example, "financial accountability"). 
2. This mismatch of shareholder rights and stakeholder rights is one reason for the discussion on corporate social responsibility (CSR). For the purpose of analytical strictness, we distinguish CSR from the accountability of private actors, although CSR and accountability seem to have some crucial similarities because both aim at matching corporate action with social objectives and values. In contrast to accountability, however, CSR is a corporate activity that is voluntary, undirected, and cannot be enforced by the general public.

3. As the empirical section below shows, the different types of account giving overlap in practice. Nonetheless, we expect to gain insights into the nature of accountability by analytically distinguishing the different forms of the central question of accountability: Who accounts to whom for what?

4. These data refer to the number of hospitals. In terms of provided beds, however, public hospitals still play a major role. Most beds, especially in rural areas, are provided by them. Nonetheless, the privatization trend becomes obvious here too: Although the overall number of hospital beds has dropped sharply within the past years - especially those in public hospitals-private for-profit hospitals have managed to double their share from $7.4 \%$ in 2000 to $16.9 \%$ in 2010 (Statistisches Bundesamt, 2011).

5. In 2009, arbitration boards were invoked in about 11,000 cases (Bundesärztekammer, 2010).

6. Local political health authorities oversee compliance to legal rules such as infection protection rules.

7. Gesetz zur Reform der gesetzlichen Krankenversicherung, 2000 (changing §137 SGB V).

8. By 2008, another private hospital chain (Helios) founded the Initiative Qualitätsmedizin (IQM) together with voluntary and university hospitals. In contrast to Qualitätskliniken, the IQM is mainly based on peer review. Altogether, 126 German hospitals take part in the IQM, 45\% of them private hospitals, mainly from Helios and without any hospitals from the three private founders of Qualitätskliniken.

9. The total percentage does not add up to 100 because of rounding differences. We distinguish between public, voluntary, and private hospitals, thereby classifying university hospitals as one of these types according to their ownership.

10. Note, however, that Qualitätskliniken officially does not claim to foster competition. According to the organization's (self-)conception, it rather aims at mutual learning.

11. Competition for patients has to be distinguished from takeover battles. Because this section deals with market accountability, that is, the accountability relationship between hospitals and patients, we neglect the question of private providers competing for hospital acquisitions. In light of the transformation of the German 
hospital sector, private for-profit providers intensively compete for hospitals to acquire or to merge with.

12. There is, however, evidence from the United States that private for-profit hospitals more aggressively appeal against payment under the Medicare program than do other types of hospitals (Gray, 1991).

13. In the 2000s, initial public offerings were an intensively discussed topic in the German hospital sector. However, because German hospitals often failed to meet stock market conditions as regards size, publicity, or investor relations management, other forms of investments have gained in importance such as private equity (Albat, Kalnbach, \& Ruh, 2005).

14. If they do so voluntarily, they can choose the topic of disclosure as the example of quality indicators shows.

15. Today, the homepage does not exist anymore after ver.di in 2008 decided to go offline with the site for strategic reasons.

16. Helios and Rhön: 2001; Sana: 2003; Asklepios: only available since 2008.

17. Websites accessed on April 27, 2011.

\section{References}

Albat, A., Kalnbach, P., \& Ruh, H. (2005). Private equity als ernstzunehmende Finanzierungsoption [Private equity as an option for funding]. führen und wirtschaften, 22, 592-596.

Arrow, K. J. (1963). Uncertainty and the welfare economics of medical care. American Economic Review, 53, 941-973.

Aucoin, P., \& Heintzman, R. (2000). The dialectics of accountability for performance in public management reform. International Review of Administrative Sciences, 66, 45-55. doi:10.1177/0020852300661005

Bach, I., \& Kneist, S. (2011, June 22). Nach Betrugsermittlungen gegen Helios und DRK. Senatorin: Abrechnungsbetrug wird begünstigt [After investigation of fraud. Senator: Reimbursement facilitates fraud]. Der Tagesspiegel. Retrieved from http://www.tagesspiegel.de

Bode, I. (2010). Die Malaise der Krankenhäuser [The malaise of hospitals]. Leviathan, 38(2), 189-211.

Böhlke, N., Gerlinger, T., Mosebach, K., Schmucker, R., \& Schulten, T. (Eds.). (2009). Privatisierung von Krankenhäusern. Erfahrungen und Perspektiven aus Sicht der Beschäftigten [Privatization of hospitals. Experiences and perspectives from the point of view of employees]. Hamburg, Germany: VSA-Verlag.

Bovens, M. (2005). Public accountability. In E. Ferlie, L. E. Lynn Jr., \& C. Pollitt (Eds.), The oxford handbook of public management (pp. 182-208). New York, NY: Oxford University Press.

Bovens, M. (2010). Two concepts of accountability: Accountability as a virtue and as a mechanism. West European Politics, 33, 946-967. 
Breiholz, J. (2008, June). Missglückte Operation [Unsuccessful operation]. Die Mitbestimmung, pp. 10-15.

Bruckenberger, E., Klaue, S., \& Schwintowski, H.-P. (2006). Krankenhausmärkte zwischen Regulierung und Wettbewerb [Hospital markets between regulation and competition]. Berlin, Germany: Springer.

Bundesärztekammer. (2010). Wegweiser: Gutachterkommissionen und Schlichtungsstellen bei den Ärztekammern [Guide: Advisory and arbitration at the medical associations]. Berlin, Germany: Author.

Bundeskartellamt. (2005). Fusionskontrolle Rhön (b 10 - 123/04) [Merger control Rhön]. Bonn, Germany: Author.

Coase, R. H. (1937). The nature of the firm. Economica, 4, 386-405. doi:10.1111/ j.1468-0335.1937.tb00002.x

Coordes, G. (2008, September 23). Missstände in Krankenhäusern: Anonym per Internet beschweren [Deficiency in hospitals: Raising complaints anonymously via the internet]. Frankfurter Rundschau. Retrieved from http://www.fr-online.de

Day, P., \& Klein, R. (1987). Accountabilities: Five public services. London, England: Tavistock.

Dent Mike, Howarth Chris, Mueller Frank, Preuschoft Claudia (2004). Archetype transition in the German health service? The attempted modernization of hospitals in a North German state. Public Administration, 82 (3), 727 -742.

DiMaggio, P. J., \& Powell, W. W. (1983). The iron cage revisited: Institutional isomorphism and collective rationality in organizational fields. American Sociological Review, 48, 147-160.

Gray, B. H. (1991). The profit motive and patient care. The changing accountability of doctors and hospitals. Cambridge, MA: Harvard University Press.

Hodge, G. A., \& Coghill, K. (2007). Accountability in the privatized state. Governance: An International Journal of Policy, Administration, and Institutions, 20, $675-702$.

Kirkpatrick, I., Jespersen, P. K., \& Dent, M. (2009). Medicine and management in a comparative perspective: The case of Denmark and England. Sociology of Health \& Illness, 31, 642-658.

Koenig-Archibugi, M. (2004). Transnational corporations and public accountability. Government and Opposition, 39, 234-259. doi:10.1111/j.1477-7053.2004.00122.x

Kuhlmann, E. (2006). Modernizing health care. Reinventing professions, the state, and the public. Bristol, UK: Policy Press.

Kuhlmann, E., \& Burau, V. (2008). The healthcare state in transition. European Societies, 10, 619-633.

Leazes, F. J. (1997). Public accountability. Administration \& Society, 29, 395-411. doi:10.1177/009539979702900401 
Luke, B. (2010). Examining accountability dimensions in state-owned enterprises. Financial Accountability \& Management, 26, 134-162.

Mattei, P. (2009). Restructuring welfare organizations in Europe: From democracy to good management? Basingstoke, UK: Palgrave Macmillan.

MDK Gemeinschaft. (2010). Abrechnungsprüfungen der MDK in Krankenhäusern sind angemessen, wirtschaftlich und zielführend. Zahlen und Fakten der MDKGemeinschaft [Accounting inquiries of the MDK in hospitals are appropriate, efficient and target-aimed. Numbers and facts of the MDK community]. Positionspapier der MDK-Gemeinschaft (Stand 22. November 2010). Retrieved from http://www.mds-ev.de/media/pdf/MDK-Informationspapier-KH-Abrechnungspruefung.pdf

Meuerer, C. (2008). Außergerichtliche Streitbeilegung in Arzthaftungssachen. Berlin, Germany: Springer.

Meyer, J., \& Rowan, B. (1977). Institutional organizations: Formal structure as myth and ceremony. American Journal of Sociology, 83, 340-363.

Moes, J., Berthoin Antal, A., Hofmann, J., \& Oppen, M. (2008). Accountability-Beziehungen im Wandel: ein sozialwissenschaftlicher Zugang [Changing accountability relations: A social science approach]. (WZB Discussion Papers, SP III 2008-104). Berlin, Germany: WZB.

Mosebach, K. (2009). Commercializing German hospital care? Effects of new public management and managed car under neoliberal conditions. Germany Policy Studies, 5, 65-98.

Mulgan, R. (2000). Comparing accountability in the public and private sectors. Australian Journal of Public Administration, 59, 87-97.

Penter, V., Arnold, C., Eifler, D., \& Friedrich, S. (2009). Abhängigkeit der Kliniken von den Banken wächst [Dependence of hospitals on banks is growing]. führen und wirtschaften, 26, 592-594.

Rhön-Klinikum AG. (2010). Rhön-Klinikum AG 2009. Retrieved from http://rhk. gb09.corporate-publications.com/images/stories/pdf/GB_Rhoen_Klinikum_AG_ ONLINE_Englisch.pdf

Sana Kliniken AG. (2010, April 12). Klartext statt Fachchinesisch: Klinikvergleich per Mausklick seit heute online (press release). Available from http:/www.sana.de

Scharpf, F. W. (1997). Games real actors play. Actor-centered institutionalism in policy research. Boulder, CO: Westview.

Statistisches Bundesamt. (2011). Gesundheit: Grunddaten der Krankenhäuser 2010. Wiesbaden, Germany: Author.

Trebilcock, M. J., \& Iacobucci, E. M. (2003). Privatization and accountability. Harvard Law Review, 116, 1422-1453.

Tuohy, C. H. (2003). Agency, contract, and governance: Shifting shapes of accountability in the health care arena. Journal of Health Politics, Policy and Law, 28, 195-215. 
Wendt, C., Frisina, L., \& Rothgang, H. (2009). Healthcare system types: A conceptual framework for comparison. Social Policy \& Administration, 43, 85-105.

\section{Author Biographies}

Tanja Klenk is an interim professor for political science, administration and organization at the Faculty of Economics and Social Sciences at Potsdam University (Germany). Her principal research interests lie in the field of social policy, administration, and governance. Her work has been published in Public Management Review, Comparative Governance and Politics, and dms-Der Moderne Staat. Currently she is working on the subject of "Marketizing welfare governance. Governing welfare markets and welfare industries".

Jonas Pieper is a doctoral fellow at the Centre for Social Policy Research, University of Bremen (Germany). He is pursuing a $\mathrm{PhD}$ by analyzing the characteristics and strategies of private firms providing social goods and services. 